\title{
PENGARUH PENGGUNAAN STRATEGI PETA KONSEP TERHADAP HASIL BELAJAR IPS PESERTA DIDIK DI SMP
}

\author{
Sahra, Muhsinatun Siasah Masruri \\ SMPN 1 Plampang, Universitas Negeri Yogyakarta \\ sahramastar@gmail.com
}

Abstrak

Penelitian ini bertujuan untuk mengetahui pengaruh strategi peta konsep terhadap hasil belajar IPS di SMP Negeri I Unter Iwes Sumbawa Tahun Ajaran 2012/2013. Penelitian ini merupakan penelitian quasi eksperimen dengan rancangan faktorial $2 \times 2$. Subjek dalam penelitian ini adalah peserta didik kelas VII.1 SMPN 1 Unter Iwes sebagai kelompok eksperimen dan kelas VII.1 SMPN 2 Sumbawa sebagai kelompok kontrol. Data diperoleh dengan: (1) tes, untuk mengukur pemahaman peserta didik terhadap konsep IPS, dan (2) angket dengan skala likert, untuk menggolongkan peserta didik dengan minat IPS dan non IPS. Untuk validasi empiris, instrumen diujicobakan pada siswa kelas VIII-4 dan VIII-6 SMP Negeri 1 Unter Iwes Sumbawa dengan hasil 46 butir angket yang valid dari 75 butir, dan untuk soal tes hasil belajar, terdapat 30 butir yang valid dari 40 butir soal. Data dianalisis menggunakan analisis variansi dua jalan. Hasil penelitian menunjukkan bahwa: (1) strategi pembelajaran peta konseplebih efektif untuk meningkatkan hasil belajar IPS yang komprehensif dari pada strategi ceramah (dengan rataan 76,47 > 68,69; $\mathrm{Fo}=8,84 ; \alpha 0,05$ ); (2) hasil belajar peserta didik dengan minat IPS lebih tinggi dibandingkan hasil belajar peserta didik minat non IPS (dengan rataan 73,59 > 72,10; Fo = 7,09; $\alpha 0,05$ ); dan (3) terdapat interaksi pengaruh antara strategi pembelajaran dan minat terhadap hasil belajar dengan $(\mathrm{Fo}=12,98$; pada 0,05$)$. Dengan demikian strategi peta konsep lebih efektif daripada strategi ceramah untuk meningkatkan hasil belajar IPS. Oleh karena itu peta konsep dapat digunakan sebagai pembelajaran IPS untuk mencapai hasil belajar, terutama pada siswa yang minat IPS.

Kata Kunci: peta konsep, minat dan hasil belajar

\section{THE EFFECT OF THE CONCEPT MAPPING TEACHING STRATEG TO IMPROVE THE SOCIAL STUDIES LEARNING ACHIEVEMEANT}

\author{
Sahra, Muhsinatun Siasah Masruri \\ SMPN 1 Plampang, Universitas Negeri Yogyakarta \\ sahramastar@gmail.com
}

\begin{abstract}
This study aims to reveal the effect of the concept mapping teaching strategy to improve the Social Studies learning avhievement in SMP Negeri 1 Unter lwes Sumbawa in the academic year of 2012/2013. This was a quasi-experimental study using a factorial two by two design. The research subjects consisted of Class VII.1 students of SMPN 1 Unter Iwes as the experimental group and Class VII.1 students of SMPN 2 Sumbawa as the control group. The data were collected through (1) a test to measure the students 'understanding of Social Studies concepts and (2) a Likert-scale questionnaire to classify their interest in Social Studies and nonSocial Studies. The constructed instruments were first validated through experts judgment by Social Studies experts. For the empirical validity, the instruments were tried out to Class VIII-4 and VIII-6 students of SMP Negeri 1 Unter Iwes Sumbawa, resulting in 46 valid questionnaire items out of 75 items and 30 valid learning achievement test items out of 40 items. The data were analyzed using a two-way analysis of variance. The results of the study show that: (1) the concept mapping teaching strategy is more effective to improve the Social Studies learning achievement than the lecturing strategy (with a mean of 76.47>68.69; Fo=8.84; $\alpha=0.05)$; (2) the learning achievement of the students with the interest in Social Studies is higher than that of those with the interest in non-Social Studies (with a mean of 73.59>72.10; Fo=7.09; $\alpha=0.05$ ); and (3) there is an interaction of the effects of the learning strategies and interest on learning achievement $(F o=12.98$; $\alpha=0.05)$. Therefore, the concept mapping strategy is more effective than the lecturing strategy to improve the Studies teaching achievement. As a result, the concept mapping can be used in Social Studies learning in order to attain learning achievement, especially among the students with the interest in Social Studies.
\end{abstract}

Keywords: effectiveness, concept mapping, learning interest 


\section{Pendahuluan}

Belajar merupakan kebutuhan mendasar bagi manusia dalam perkembangannya menghadapi perubahan zaman dan perkembangan ilmu pengetahuan. Aktivitas yang penting ini tidak dapat dipisahkan dari kehidupan manusia sejak lahir sampai akhir hayat karena pendidikan merupakan kebutuhan manusia sepanjang hidup dan selalu berubah mengikuti perkembangan zaman.

Menurut Undang-Undang Republik Indonesia nomor 14 tahun 2005 Pasal 1 tentang guru dan dosen "Guru adalah pendidik profesional dengan tugas utama mendidik, mengajar, membimbing, mengarahkan, melatih, menilai, dan mengevaluasi peserta didik pada pendidikan anak usia dini jalur pendidikan formal, pendidikan dasar, dan pendidikan menengah". Proses pembelajaran bagi guru perlu direncanakan, dilaksanakan, dinilai, dan diawasi agar terlaksana secara efektif dan efisien.

Pada proses belajar, tindakan manusia dalam bersikap dan bertingkah laku tidak hanya sekedar menanggapi rangsangan dari luar dirinya, tapi juga ada faktor tertentu dari dalam diri yang mendorong untuk melakukan perbuatan yaitu minat.

Menurut Slameto (2010, p.180) minat adalah suatu rasa lebih suka dan rasa keterikatan pada suatu hal atau aktivitas, tanpa ada yang menyuruh. Minat merupakan serangkaian usaha untuk menumbuhkan keinginan terhadap sesuatu sehingga mendorongnya untuk memberikan perhatian yang besar terhadap hal tersebut. Minat dapat muncul dan berubah karena adanya pengaruh-pengaruh seperti lingkungan dan kebutuhan. Tentunya dalam kegiatan dan usaha pencapaian tujuan perlu adanya pendorong untuk menumbuhkan minat.

Untuk menumbuhkan minat belajar IPS pada peserta didik, sangat berhubungan dengan semangat guru dalam mengajar. Guru yang mempunyai semangat yang besar dalam mengajar materi akan mempengaruhi minat peserta didik terhadap materi yang diajarkan. Tidak mungkin seorang guru dapat membangkitkan minat peserta didik, jika guru sendiri tidak memiliki minat dalam memberikan materi pembelajaran di kelas. Guru dalam proses pembelajarannya harus interaktif, inspiratif, menyenangkan, menantang, dan memotivasi peserta didik untuk berpartisifasi aktif, serta memberi ruang yang cukup bagi prakarsa, kreativitas, kemandirian sesuai dengan bakat, minat, dan perkembangan fisik serta psikologis peserta didik.

Pendidikan menuntut adanya pembenahan dan penyempurnaan terhadap aspek subtansif yang mendukungnya, terutama standar kompetensi lulusan dan tenaga kependidikan yang melaksanakannya. Selain itu juga perlu diterapkan strategi, model, strategi, pendekatan, dan metode pembelajaran yang sesuai dengan kompetensi yang harus dikuasai oleh peserta didik. Hal ini bertujuan, untuk mempermudah peserta didik dalam upaya menguasai kompetensi-kompetensi yang dipersyaratkan untuk menyelesaikan belajarnya pada jenjang sekolah.

Menurut Diane Ronis (Hartati Widiastuti, 2011, p.87) isi pembelajaran merupakan unsur sangat penting untuk memastikan pendidikan berkualitas tinggi bagi setiap peserta didik. Oleh karena itu, isi pendidikan perlu disampaikan dengan cara yang sesuai dan gaya guru melaksanakan pembelajaran mempengaruhi hasil belajar peserta didik. Guru yang baik menggunakan strategi berbeda, pada waktu berbeda, untuk tujuan berbeda.

Ilmu Pengetahuan Sosial (IPS) berkaitan dengan cara mencari tahu tentang kehidupan sosial manusia. IPS dikatakan sebagai studi mengenai integrasi ilmu-ilmu sosial dan humaniora dalam menelaah gejala dan masalah sosial yang terjadi di masyarakat (Nursid Sumaatmadja, 1980, p.1.9). Kompetensi IPS bukan hanya penguasaan sekumpulan pengetahuan yang berupa faktafakta, konsep-konsep, atau prinsip-prinsip saja, tetapi juga merupakan proses aplikasinya. Pendidikan IPS diharapkan dapat menjadi wahana bagi peserta didik untuk mempelajari diri sendiri, serta prospek pengembangan lebih lanjut dalam penerapannya pada kehidupan sehari-hari.

Peraturan Menteri Pendidikan Nasional Republik Indonesia Nomor 22 tahun 2006 tentang Standar Isi untuk Pendidikan Dasar dan Menengah memuat Pembelajaran Ilmu Pengetahuan Sosial (IPS) sebagai salah satu mata pelajaran yang diberikan mulai dari SD/MI/ SDLB sampai SMP/MTs/SMPLB.

Pelaksanaan pembelajaran IPS saat ini masih didominasi oleh metode konvensional 
(ceramah) dan selama ini guru hanya berupaya mengembangkan dan menguji daya ingat peserta didik, sedangkan kemampuan berpikir rasional dan kreatif kurang di aktifkan. Pengembangan kemampuan berpikir kritis dan kreatif terhambat oleh kemampuan mengingat. Guru lebih mengedepankan pengembangan otak anak sebagai organ perekam bukan sebagai organ berpikir.

Menurut Bloom (Iif Khoiru, Sofan \& Tatik, 2011, p.96) perilaku peserta didik sebagai tujuan pembelajaran yang komprehensif dapat diklasifikasikan dalam tiga ranah atau kawasan yaitu:

1. Kawasan kognitif yaitu kawasan yang berkaitan aspek-aspek intelektual atau berpikir/ nalar, di dalamnya mencakup: pengetahuan (knowledge), pemahaman (comprehension), penerapan (application), penguraian (analysis), memadukan (synthesis), dan penilaian (evaluation)

2. Kawasan afektif yaitu kawasan yang berkaitan aspek-aspek emosional, seperti perasaan, minat, sikap, kepatuhan terhadap moral dan sebagainya, di dalamnya mencakup: penerimaan (receiving/attending), sambutan (responding), penilaian (valuing), pengorganisasian (organization), dan karakterisasi (characterization)

3. Kawasan psikomotor yaitu kawasan yang berkaitan dengan aspek-aspek keterampilan yang melibatkan funsi sistem syaraf dan otot (neuronmuscular system) dan fungsi psikis. Kawasan ini terdiri dari kesiapan (set), peniruan (imitation), membiasakan (habitual), menyesuaikan (adaptation) dan menciptakan (origination).

Taksonomi di atas merupakan kriteria yang dapat digunakan oleh guru untuk mengevaluasi mutu dan efektivitas pembelajarannya, dengan menganalisis taksonomi perilaku tersebut, guru akan dapat menentukan dan menitikberatkan bentuk dan jenis pembelajaran yang akan dilaksanakan kepada peserta didiknya. Pembelajaran yang dapat mewujudkan ketiga ranah domain tersebut dikatakan sebagai belajar yang komprehensif.

Dalam rangka mencapai hasil belajar IPS yang komprehensif diperlukan berbagai macam strategi, termasuk strategi yang belum banyak dilakukan guru yaitu strategi pembelajaran dengan peta konsep (Concept Map). Dengan membuat peta konsep diharapkan dapat mempermudah penguasaan terhadap kompetensi pembelajaran IPS. Dengan peta konsep peserta didik tidak hanya sekedar menghapal pengertian-pengertian atau konsep-konsep, akan tetapi mampu menyusun sendiri peta konsep (Concept Map) dari suatu pengetahuannya. Peta konsep ini dapat digunakan sebagai cara untuk membangun struktur pengetahuan peserta didik dalam mencapai kompetensi yang diharapkan.

Tehnik peta konsep ini diilhami oleh teori belajar asimilasi kognitif (subsumption) dari David P. Ausubel tahun 1963 yang mengatakan bahwa belajar bermakna (meaningful learning) terjadi dengan mudah apabila konsepkonsep baru dimasukkan ke dalam konsepkonsep yang lebih inkluisif. Dengan kata lain, proses belajar terjadi bila peserta didik mampu mengasimilasikan pengetahuan yang ia miliki dengan pengetahuan yang baru (Bermawy Munthe, 2012, p.17). Strategi yang tepat dalam suatu pembelajaran, seperti dilakukan oleh Canas, et al. (2003, p.29) bahwa "in theory, advance organizer are most effective if they make the relationships among learned concepts that learners already know, thus providing a structure into which the new concepts can be integrated". Maknanya bahwa peta konsep membantu peserta didik belajar bermakna melalui penempatan dan pengintegrasian informasi baru, ke dalam struktur pengetahuan yang telah dimiliki peserta didik.

Elaine B. Johnson (2002, p.47) "we learn from science that human beings are naturally disposed to seek connections among dissimilar things, we generate a context for learning and living. Because self-regulating creatures, constantly we seek information and use it to crete our own meaning". Maksudnya kita belajar dari ilmu pengetahuan memiliki kecenderungan untuk mencari keterkaitan di antara hal-hal yang berbeda, dengan membangun keterkaitan, kita menghasilkan konteks untuk belajar dan hidup karena kita tiada henti mencari informasi dan menggunakannya untuk menciptakan makna kita sendiri.

Berdasarkan observasi yang dilakukan di SMP Negeri 1 Unter Iwes Sumbawa, dominasi 
guru selama pembelajaran masih sangat tinggi. Keadaan ini mengakibatkan peserta didik kehilangan daya kritis dan daya kreatifnya untuk menghubungkan antara pengetahuan yang didapatkannya dengan kenyataan yang dimilikinya. Orientasi guru dalam melaksanakan pembelajaran lebih terfokus pada pencapaian target yang tinggi dalam asfek kognitif sehingga seringkali mengabaikan proses pemberdayaan aspek afektif dan psikomotorik, guru juga belum memperhatikan perbedaan minat yang ada pada pada peserta didik, misalnya ada yang minat pembelajaran IPS, ada peserta didik yang minat pembelajaran non IPS. Minat ini dapat mempengaruhi pencapaian hasil belajar peserta didik secara komprehensif.

Untuk itu, maka diperlukan pemilihan strategi pembelajaran yang tepat, strategi pembelajaran yang mampu mengubah paradigma pembelajaran dari peserta didik sebagai objek, menjadi subjek atau pelaku dari proses pembelajaran. Strategi pembelajaran yang mampu mengikutsertakan semua peserta didik untuk mendapatkan peran, mampu mengembangkan kemampuan dasar dan sikap positif sehingga proses pembelajaran menjadi lebih menarik, menantang, menyenangkan dan mengaktifkan semua aspek dari dalam diri peserta didik.

Pembelajaran IPS dengan menggunakan peta konsep di SMP Negeri 1 Unter Iwes di Sumbawa diharapkan dapat meningkatkan hasil belajar kognitif, sikap positif, serta perilakuperilaku yang relevan dalam kehidupan seharihari peserta didik di masyarakat. Melalui peta konsep yang dibangun bersama-sama dengan guru, diharapkan hasil yang diperoleh dalam pembelajaran IPS lebih komprehensif dan meningkat.

Rumusan masalah dalam penelitian ini adalah : (1) Apakah pencapaian hasil belajar IPS dengan strategi peta konsep lebih tinggi darnon IPSda strategi ceramah di SMPN 1 Unter Iwes Kabupaten Sumbawa; (2) Apakah hasil belajar IPS pada peserta didik dengan minat IPS lebih tinggi darnon IPSda hasil belajar IPS pada peserta didik dengan minat non IPS di SMPN 1 Unter Iwes Kabupaten Sumbawa; (3) Apakah ada interaksi pengaruh peta konsep dan minat peserta didik dalam pencapaian hasil belajar IPS yang komprehensif di SMPN 1 Unter Iwes Kabupaten Sumbawa.

Berdasarkan rumusan masalah di atas maka secara garis besar penelitian ini bertujuan: (1) Untuk mengetahui keefektifan strategi peta konsep dibandingkan dengan strategi ceramah untuk mencapai hasil belajar IPS yang komprehensif di SMPN 1 Unter Iwes Kabupaten Sumbawa. (2) Untuk mengetahui perbedaan hasil belajar antara peserta didik dengan minat IPS dan minat non IPS yang komprehensif di SMPN 1 Unter Iwes Kabupaten Sumbawa. (3) Untuk mengetahui interaksi pengaruh peta konsep dan minat peserta didik dalam pencapaian hasil belajar IPS yang komprehensif di SMPN 1 Unter Iwes Kabupaten Sumbawa.

Setelah penelitian ini selesai diharapkan dapat memberikan manfaat sebagai berikut: (1) Manfaat Teoritis yaitu Penelitian ini dapat memberikan gambaran dan pengetahuan dalam penerapan peta konsep/Concept Mappada pelajaran IPS. (2) Manfaat Praktis: (a) Bagi guru, hasil penelitian ini dapat memberikan suatu alternatif strategi pembelajaran, yang dapat meningkatkan kualitas pembelajaran IPS untuk tingkat SMP dan dapat juga sebagai contoh bagi guru IPS lainnya (b) Bagi peserta didik, strategi pembelajaran dengan peta konsep ini diharapkan dapat meningkatkan minat dan pemahaman konsep dalam pembelajaran IPS. (c) Bagi sekolah, meningkatkan efektivitas pembelajaran di sekolah dan meningkatkan prestasi sekolah melalui peningkatan prestasi belajar peserta didik dan sebagai acuan untuk pengembangan model pembelajaran IPS dalam mengajar di kelas.

\section{Metode Penelitian}

Jenis Penelitian

Penelitian ini merupakan penelitian kuantitatif dengan menggunakan jenis penelitian ekserimen semu (quasi-experiment research).

Desain Penelitian

Desain penelitian yang digunakan dalam penelitian ini adalah menggunakan factorial design atau rancangan faktorial (Sukardi, 2011, p.186). Desain penelitian ini digambarkan pada tabel 1. 
Tabel 1. Rancangan analisis faktorial 2 x 2

\begin{tabular}{cccc}
\hline Minat & Kelompok & $\begin{array}{c}\text { Strategi } \\
\text { peta konsep }\end{array}$ & $\begin{array}{c}\text { Strategi } \\
\text { ceramah }\end{array}$ \\
\hline IPS & A1B1 & A2B1 \\
Non IPS & A1B2 & A2B2 \\
\hline
\end{tabular}

Keterangan:

A1BI : Strategi peta konsep dengan peserta didik minat IPS

A1B2: Strategi peta konsep dengan peserta didik minat non IPS

A2B1: Strategi ceramah dengan peserta didik minat IPS

A2B2: Strategi ceramah dengan peserta didik minat non IPS

Waktu dan Tempat Penelitian

Penelitian ini dilakukan di SMP Negeri 1 Unter Iwes Sumbawa. Penelitian ini dilaksanakan bulan Januari sampai Februari 2013 pada peserta didik kelas V11.1 semester II tahun pelajaran 2012/2013.

Subjek Penelitian

Subjek dalam penelitian ini sebagai kelompok eksperimen adalah peserta didik kelas VII.1 di SMPN 1 Unter Iwes.Kelompok kontrol adalah peserta didik kelas VII.1 di SMPN 2 Sumbawa.Penentuan kelas yang akan dijadikan kelompok eksperimen dengan acak (random). Pada kelompok eksperimen pembelajaran dilaksanakan dengan (treatment) strategi peta konsep, sedangkan kelompok kontrol pembelajaran dilaksanakan dengan strategi ceramah. Kedua kelompok tersebut diberi tahapan perlakuan yang sama, yaitu pretest, kemudian dilaksanakan pembelajaran 4 kali pertemuan dengan materi asmosfer dan hidrosfer, setelah itu diberi posttest.

Variabel Penelitian

Variabel bebas dalam penelitian ini adalah pembelajaran IPS dengan peta konsep dan minat peserta didik. Variabel terikat dalam penelitian ini adalah hasil belajar IPS pada peserta didik secara komprehensif.

- Strategi peta konsep merupakan strategi untuk menggali ke dalam struktur kognitif pelajar dan untuk mengetahui, baik bagi pelajar maupun guru, melihat apa yang telah diketahui pelajar dengan mengaitkan konsep yang telah dimiliki peserta didik dengan konsep baru.
- Minat adalah kecenderungan yang tetap untuk memperhatikan dan mengenang beberapa kegiatan watak, yang tersusun melalui pengalaman yang mendorong individu mencari objek, aktivitas, pengertian, keterampilan untuk tujuan perhatian atau penguasaan. Pada penelitian ini peneliti memberi angket pilihan minat kepada peserta didik yaitu minat pada pembelajaran IPS dan minat non IPS.

- Hasil Belajar IPS yang komprehensif adalah hasil belajar peserta didik yang kognitif, afektif dan psikomotoriknya tinggi dalam pembelajaran IPS yang komprehensif.

Teknik dan Instrumen Pengumpulan Data

Data dikumpulkan melalui pemberian angket minat dan tes hasil belajar. Instrumen pengumpulan data dalam penelitian ini terdiri dari instrumrn angket minat IPS dan Non IPS untuk mengetahui minat peserta didik, lembar soal tes untuk mengetahui hasil belajar IPS peserta didik secara komprehensif.

Validitas dan Reliabilitas Instrumen

Validitas yang digunakan dalam penelitian ini adalah validitas isi dan validitas construct. Untuk instrumen angket dan tes hasil belajar memerlukan bukti validitas isi dan validitas konstruk. Pada instrument angket minat menggunakan SPSS windows 16.00 dengan hasil 46 butir angket yang valid dari 75 butir, dan hasil tes hasil belajar dilakukan juga daya beda iteman. Untuk soal tes hasil belajar, terdapat 30 butir yang valid dari 40 butir soal. Hasil uji reliabilitas instrumen terhadap minat belajar IPS adalah 0,863 , dan minat belajar Non IPS adalah 0,835 menunjukkan bahwa instrumen minat belajar bisa dikatakan reliabel karena koefisein alfanya di atas 0,70 . Untuk hasil belajar IPS adalah 0,949 menunjukkan angka di atas 0,7 bisa dikatakan reliabel. Ini berarti soal untuk mengukur hasil belajar IPS bisa dikatakan reliabel.

Teknik Analisis Data

Sebelum analisis data dilakukan uji prasyarat analisis yang terdiri dari uji normalitas dan uji homogenitas. Statistik deskriptif digunakan untuk menyajikan data hasil angket minat dan hasil tes belajar peserta didik yang komprehensif dalam bentuk tabel, gambar, diagram maupun grafik 
sehingga mudah dipahami. Analisis inferensial yang digunakan adalah variansi dua jalan.

\section{Hasil Penelitian dan Pembahasan}

Sebelum pelaksanaan eksperimen dilaksanakan. Adapun data hasil angket minat berdasarkan kelompok minat IPS dan non IPS disajikan pada tabel berikut ini:

Tabel 2. Data Minat Peserta Didik

\begin{tabular}{|c|c|c|}
\hline Minat & Eksperimen & Kontrol \\
\hline IPS & 23 & 25 \\
\hline Non IPS & 13 & 17 \\
\hline
\end{tabular}

Sesudah eksperimen dilaksanakan, maka kedua kelompok sampel tersebut diberikan tes hasil belajar dengan materi atmosfer dan hidrosfer dengan memperoleh data sebagai berikut:

Tabel 3. Data Hasil Belajar IPS Kelompok Eksperimen Postes

\begin{tabular}{lcc}
\hline Banyaknya Anggota & $\mathbf{n}$ & $\mathbf{3 6}$ \\
\hline Skor Tertinggi & $\mathrm{X}_{\text {mak }}$ & 93,33 \\
Skor Terendah & $\mathrm{X}_{\text {min }}$ & 60 \\
Rataan & $\overline{\mathrm{X}}$ & 76,47 \\
Variansi & $\mathrm{s}^{2}$ & 89,09 \\
Standar Deviasi & $\mathrm{S}$ & 9,44 \\
\hline
\end{tabular}

Tabel 4. Data Hasil Belajar IPS Kelompok Kontrol Postes

\begin{tabular}{lcc}
\hline Banyaknya Anggota & $\mathbf{n}$ & $\mathbf{4 2}$ \\
\hline Skor Tertinggi & $\mathrm{X}_{\text {mak }}$ & 86,66 \\
Skor Terendah & $\mathrm{X}_{\min }$ & 53,33 \\
Rataan & $\overline{\mathrm{X}}$ & 68,69 \\
Variansi & $\mathrm{s}^{2}$ & 70,18 \\
Standar Deviasi & $\mathrm{s}$ & 8,37 \\
\hline
\end{tabular}

Berdasarkan data pada tabel 3 dan 4 tersebut, maka hasil analisis data statistik deskriptif menunjukkan bahwa skor tertinggi pada kelompok eksperimen dengan strategi peta konsep sebesar 93,33, skor terendah sebesar 60 dan untuk rata-rata nilai post test adalah sebesar 76,47. Sedangkan kelompok kontrol dengan strategi ceramahskor tertinggi sebesar 86,66, skor terendah sebesar 53,33 dan untuk rata-rata nilai posttest adalah sebesar 68,69 . Adapun data hasil belajar siswa berdasarkan kelompok minat IPS dan non IPS disajikan pada tabel berikut ini:

Tabel 5. Data Hasil Belajar IPS Kelompok minat IPS

\begin{tabular}{lcc}
\hline Banyaknya Anggota & $\mathbf{N}$ & $\mathbf{4 8}$ \\
\hline Skor Tertinggi & $\mathrm{X}_{\text {mak }}$ & 93,33 \\
Skor Terendah & $\mathrm{X}_{\text {min }}$ & 53,33 \\
Rataan & $\bar{X}$ & 72,74 \\
Variansi & $\mathrm{s}^{2}$ & 92,64 \\
Standar Deviasi & $\mathrm{S}$ & 10,19 \\
\hline
\end{tabular}

Tabel 6. Data Hasil Belajar IPS Kelompok minat non IPS

\begin{tabular}{lcc}
\hline \multicolumn{1}{c}{ Banyaknya Anggota } & $\mathbf{N}$ & $\mathbf{3 0}$ \\
\hline Skor Tertinggi & $\mathrm{X}_{\text {mak }}$ & 90 \\
Skor Terendah & $\mathrm{X}_{\min }$ & 60 \\
Rataan & $\bar{X}$ & 71,54 \\
Variansi & $\mathrm{s}^{2}$ & 58,16 \\
Standar Deviasi & $\mathrm{s}$ & 7,63 \\
\hline
\end{tabular}

Hasil belajar IPS yang komprehensif tersebut diuji signifikansinya dengan menggunakan Uji analisis variansi dua jalan. Hasil perhitungan analisis variansi dua jalan terhadap hasil belajar IPS yang komprehensif peserta didik sesudah eksperimen disajikan dalam tabel 7 berikut ini:

Tabel 7. Ringkasan Tabel Hasil Perhitungan Anava Dua Jalan

\begin{tabular}{lcccccc}
\hline \multicolumn{1}{c}{ Sumber Variasi } & $\mathbf{J K}$ & $\mathbf{d b}$ & $\mathbf{R K}$ & $\mathbf{F}_{\mathbf{o}}$ & $\mathbf{F}_{\mathbf{t}}$ & Keputusan Uji \\
\hline Strategi & 12935,02 & 1 & 12935,02 & 8,84 & 3,970 & Ho Ditolak \\
Minat & 10810,18 & 1 & 10810,18 & 7,09 & 3,970 & Ho Ditolak \\
Interaksi & 19741,21 & 1 & 19741,21 & 12,98 & 3,970 & Ho Ditolak \\
Dalam kelompok & 112747,6 & 74 & & & & \\
Total & 156234,01 & 77 & & & & \\
\hline
\end{tabular}


Hasil analisis berdasarkan pada Tabel 7 di atas, menunjukkan bahwa perbedaan hasil belajar IPS yang komprehensif dengan strategi peta konsep dan strategi ceramah, diperoleh $\mathrm{F}_{\mathrm{o}}=$ $8,84>\mathrm{F}_{\mathrm{t}}=3,970$ pada $\alpha 0,05$, maka $\mathrm{H}_{0 \mathrm{~A}}$ ditolak. Artinya bahwa hasil belajar dengan strategi peta konsep lebih tinggi dari pada hasil belajar dengan strategi ceramah, dengan demikian strategi peta konsep lebih efektif daripada strategi ceramah.

Hasil analisis perbedaan hasil belajar berdasarkan minat, menunjukkan bahwa perbedaan hasil belajar antara peserta didik dengan minat IPS dan minat non IPS, diperoleh $\mathrm{F}_{\mathrm{o}}=7,09>$ $\mathrm{F}_{\mathrm{t}}=3,970$ pada $\alpha 0,05$, maka Ho dapat ditolak. Dengan demikian berarti terdapat perbedaan hasil belajar antara peserta didik dengan minat IPS dan minat non IPS (Hasil belajar kelompok peserta didik minat IPS lebih tinggi dibandingkan hasil belajar kelompok peserta didik minat non IPS).

Hasil analisis interaksi, diperoleh $\mathrm{F}_{\mathrm{o}}=$ 674,14 $>\mathrm{F}_{\mathrm{t}}=3,970$ maka Ho dapat ditolak. Artinya ada interaksi pengaruh peta konsep dan minat peserta didik dalam pencapaian hasil belajar IPS yang komprehensif. Interaksi di atas dapat dilihat pada diagram berikut:

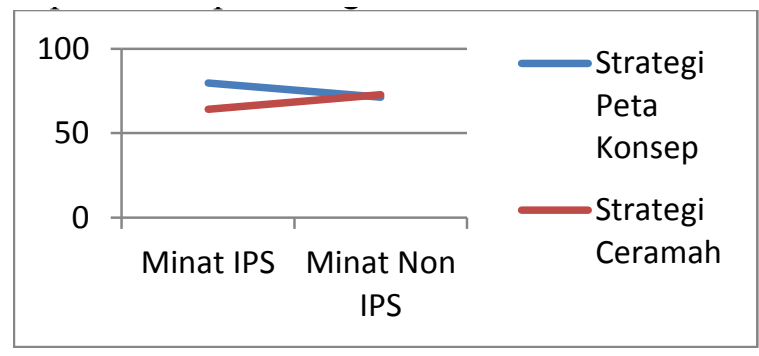

Gambar 1. Diagram interaksi pengaruh peta

konsep dan minat peserta didik dalam pencapaian hasil belajar IPS yang komprehensif.

Pembahasan

\section{Hipotesis Pertama}

Hasil belajar IPS peserta didik yang belajar dengan strategi pembelajaran peta konsep lebih tinggi jika dibandingkan dengan hasil belajar IPS peserta didik yang belajar dengan strategi pembelajaran ceramah.

Dari hasil analisis variansi dua jalan dinyatakan bahwa $\mathrm{H}_{0}$ dapat ditolak, artinya kedua strategi pembelajaran mempunyai rataan yang tidak sama. Ini berarti bahwa hipotesis dalam penelitian ini yang menyatakan bahwa, hasil belajar IPS yang komprehensif peserta didik yang belajar dengan strategi pembelajaran peta konsep lebih tinggi dari hasil belajar IPS peserta didik yang belajar dengan strategi pembelajaran ceramah diterima. Jadi dapat dikatakan bahwa strategi pembelajaran dengan peta konseplebih efektif jika dibandingkan dengan strategi pembelajaran ceramah. Hasil belajar IPS yang komprehensif dengan strategi peta konsep, nilai rata-rata postes yaitu 76,47 sedangkan hasil belajar IPS yang komprehensif dengan strategi ceramah, nilai rata-rata postes yaitu 68,69 .

Pada proses pembelajaran yang diterapkan diharapkan berpusat pada peserta didik dan bukan pada pendidik. Oleh karena itu, diperlukan berbagai macam usaha untuk mewujudkan proses pembelajaran yang memberikan kesempatan kepada peserta didik untuk mengembangkan potensi dirinya dalam mencapai tujuan pembelajaran yang lebih maksimal, salah satu usaha untuk mencapai tujuan tersebut adalah dengan melakukan dan menerapkan suatu strategi pembelajaran.

Srategi pembelajaran dapat dipahami sebagai sesuatu yang tidak terjadi secara kebetulan, melainkan sistematis, dan mampu meningkatkan partisipasi aktif peserta didik sesuai dengan situasi, kebutuhan, dan tujuan tertentu serta pendekatan yang digunakan. Pada proses pembelajaran yang diterapkan diharapkan berpusat pada peserta didik dan bukan pada pendidik. Oleh karena itu, diperlukan berbagai macam usaha untuk mewujudkan proses pembelajaran yang memberikan kesempatan kepada peserta didik untuk mengembangkan potensi dirinya dalam mencapai tujuan pembelajaran yang lebih maksimal, maka dari itu salah satu usaha untuk mencapai tujuan tersebut adalah dengan melakukan dan menerapkan suatu strategi pembelajaran. Setiap suatu strategi pembelajaran yang ada tidak akan menjamin bisa efektif jika tidak diterapkan pada setiap kompetensi dasar atau pada materi pelajaran IPS. Oleh karena itu, sangat dibutuhkan sebuah eksperimentasi terhadap suatu strategi pembelajaran. Penelitian yang telah dilakukan yaitu menggunakan strategi pembelajaran peta konsep dalam meningkatkan hasil belajar IPS 
yang komprehensif di SMP Negeri 1 Unter Iwes Kabupaten Sumbawa dengan materi atmosfer dan hidrosfer.

\section{Hipotesis Kedua}

Mengetahui perbedaan hasil belajar antara peserta didik dengan minat IPS dan minat non IPS yang komprehensif di SMPN 1 Unter Iwes Kabupaten Sumbawa.

Dari uji analisis variansi dua jalan dinyatakan bahwa $\mathrm{H}_{0}$ dapat ditolak artinya di antara kelompok minat IPS dan kelompok minat non IPS mempunyai rataan yang sama. Hasil belajar IPS siswa dalam kelompok minat IPS yaitu 73,59 dan kelompok minat non IPS 72,10. Dari hasil belajar tersebut dapat dilihat bahwa hasil belajar peserta didik dengan minat IPS lebih tinggi daripada hasil belajar peserta didik yang minat non IPS.

Pada proses pembelajaran, peran atau posisi guru dengan strategi peta konsep berbeda dengan pembelajaran menggunakan srategi ceramah. Pada pembelajaran dengan strategi ceramah peserta didik cenderung pasif dalam proses belajar mengajar sehingga kurang efektif, guru cenderung mendominasi dan memegang peran utama dalam pengajaran, sehingga kegiatan belajar cenderung sama yang diberikan oleh guru, karena dianggap cara itu paling mudah untuk mengontrol ketenangan dalam kelas. Akibatnya peserta didik cenderung mudah jenuh, kurang inisiatif, sangat bergantung pada guru dan tidak terlatih untuk belajar mandiri.

Pemilihan metode mengajar harus disesuaikan dengan tujuan pengajaran, materi pelajaran serta bentuk pengajaran (kelompok atau individu). Setiap metode mengajar mempunyai karakteristik tertentu dengan kelebihan dan kekurangan masing-masing. Dengan memperhatikan hasil penelitian yang telah dilakukan strategi pembelajaran peta konsep lebih memberikan rangsangan kepada siswa untuk aktif dalam setiap proses pembelajaran jika dibandingkan dengan strategi ceramah.

\section{Hipotesis Ketiga}

Seperti pada pembahasan pada hipotesis kedua, hasil analisis varian dua jalan $\mathrm{Fo}=12,98$ pada $\alpha 0,05$ maka dengan demikian terdapat interaksi antara strategi peta konsep dan minat belajar terhadap hasil belajar IPS yang komprehensif pada peserta didik, artinya dapat diambil kesimpulan bahwa pada kelompok minat, hasil belajar IPS peserta didik yang belajar dengan strategi peta konsep tidak sama dengan hasil belajar IPS peserta didik yang belajar dengan strategi ceramah.

Berdasarkan hasil penelitian, tampak bahwa keterlibatan peserta didik untuk turut belajar dengan cara menggunakan peta konsep merupakan salah satu indikator keefektifan belajar. Peserta didik tidak hanya menerima saja materi dari guru, melainkan peserta didik juga berusaha menggali dan mengembangkan sendiri. Hasil belajar tidak hanya menghasilkan peningkatan pengetahuan tetapi juga meningkatkan keterampilan berpikir. Kemampuan peserta didik untuk mengerjakan soal-soal sejenis perlu dilatih, agar penerapan strategi pembelajaran peta konsep dapat lebih optimal. Kemampuan tersebut akan tampak dengan jelas bila peserta didik mampu mengerjakan soal-soal secara mandiri maupun berkelompok dengan membuat peta konsep. Kemampuan peserta didik untuk mengerjakan soal tersebut dapat dideteksi lewat kemampuannya untuk menjelaskan penyelesaian soal yang diajukannya dalam bentuk peta konsep di depan kelas. Dengan penerapan strategi pembelajaran peta konsep dapat melatih siswa belajar kreatif, disiplin, dan meningkatkan keterampilan berpikir siswa.

\section{Simpulan dan Saran}

Simpulan

Hasil eksperimen menunjukkan bahwa hasil belajar peserta didik yang belajar dengan strategi pembelajaran peta konsep lebih tinggi jika dibandingkan dengan hasil belajar siswa yang belajar dengan strategi pembelajaran ceramah. Dengan begitu maka lebih efektifnya strategi pembelajaran peta konsep diharapkan akan menghasilkan hasil belajar yang lebih baik dan masih perlu dibiasakan. Bagi peserta didik, mendapat tugas untuk membuat ide mereka menjadi peta konsep merupakan pekerjaan yang belum pernah dilakukan, sehingga dengan strategi pembelajaran peta konsep dapat dipastikan bahwa pemahaman konsep materi IPS pada peserta didik akan lebih baik. 
Hasil eksperimen menunjukkan bahwa hasil belajar IPS yang komprehensif pada peserta didik dalam kelompok minat IPS lebih tinggi terhadap hasil belajar IPS peserta didik dalam minat non IPS.

Terdapat interaksi antara strategi pembelajaran dan minat terhadap hasil belajar IPS peserta didik. Artinya dapat diambil kesimpulan bahwa strategi pembelajaran peta konsep dan minat mempengaruhi peningkatan hasil belajar IPS yang komprehensif pada peserta didik.

Saran

Berdasarkan penelitian yang telah dilakukan, maka dapat dikemukakan saran-saran sebagai berikut :

- Pelaksanaan pembelajaranIPS, guruhendaknya memadukan berbagai strategi pembelajaran baik pembelajaran yang berpusat pada guru (teacher-centered) maupun strategi pembelajaran yang berpusat pada peserta didik (student-centered). Sehingga peserta didik dapat menguasai materi yang dipelajari secara baik dan benar.

- Kepada pengajar IPS, untuk dapat menerapkan pembelajaran dengan strategi peta konsep. Terbukti lebih efektif dan pemahaman konsep peserta didik terhadap pembelajaran IPS lebih baik. Karena itu hendaknya para guru dapat mengembangkan strategi peta konsep, untuk memaksimalkan tingkat minat dan hasil belajar peserta didik dalam pembelajaran IPS.

- Untuk penelitian lebih lanjut, dapat melaksanakan strategi peta konsep dengan lebih mengaktifkan peserta didik. Agar minat dan hasil belajar pada peserta didik lebih meningkat dalam pembelajaran IPS.

\section{Daftar Pustaka}

Bermawy Munthe. (2012). Desain pembelajaran. Yogyakarta: Pustaka Insan Madani

Canas, A.J., Novak, J.D., John. W., et al. (2003). A Summary of literature pertaining to the use of concept mapping techniques and technologies for education and performance support. Pensacola. The Institute for Human and Machine Cognition, di ambil pada tanggal 7 oktober $2011 \mathrm{Http}: / / \mathrm{cmapskm}$.ihmc.us/servlet/ SBReadResourceServlet?rid

Depdiknas. (2005) Undang-Undang RI Nomor 14 tahun 2005 tentang guru dan dosen.

Depdiknas. (2006) Peraturan menteri pendidikan nasional RI Nomor 22 tahun 2006 tentang standar isi lampiran 2 standar kompetensi dan kompetensi dasar tingkat SMP/MTs dan SMPLB.

Diane Ronis. (2011). Asesmen sesuai cara kerja otak edisi kedua (terjemahan Hartati Widiastuti) Clifornia: Sage.(buku asli diterbitkan tahun 2007)

Elaine B. Johnson. (2002). Contextual teaching and learning. California: Corwin Press, INC.

Iif Khoiru Ahmadi, Sofan Amri \& Tatik Elisah. (2011). Strategi pembelajaran sekolah terpadu. Jakarta: PT. Prestasi Pustaka raya

Nursid Sumaatmadja. (2006). Konsep dasar ips. Jakarta: Universitas Terbuka

Slameto. (2010). Belajar dan faktor-faktor yang mempengaruhinya. Jakarta: Rineka Cipta. 